\title{
SCIDOC
}

\author{
International Journal of Dentistry and Oral Science (IJDOS) \\ ISSN: 2377-8075
}

\section{The Detection of Serum and Urine Levels of Alpha 2-Macroglobulin in Nasopharyngeal Carcinoma Patients Receiving Late Period Radiotherapy and its Significance}

Research Article

Chen $\mathrm{X}^{1}$, Kong $\mathrm{X}^{2}$, Cao $\mathrm{W}^{1}$, Ge $\mathrm{Y}^{1}$, Wang $\mathrm{S}^{3}$, Zhang $\mathrm{Z}^{1}$, Li H $\mathrm{H}^{1}$, Liu $\mathrm{Y}^{1}$, Fang $\mathrm{S}^{1 *}$

${ }^{1}$ Department of Oral and Maxillofacial Surgery, The Sixth Affiliated Hospital of Sun Yat-Sen University, Guangzhou, Guangdong, P.R.China.

${ }^{2}$ Department of Periodontology, Sun Yat-Sen Memorial Hospital of Sun Yat-sen University, Guangzhou, Guangdong, P.R. China.

${ }^{3}$ Department of Oncological Radiotherapy, The Fifth Affiliated Hospital of Sun Yat-Sen University, Zhuhai, Guangdong, P.R. China.

\section{Abstract}

Objective: To detect the dynamic changes of the serum and urine alpha2-macroglobulin $(\alpha 2 \mathrm{M})$ in patients with nasopharyngeal carcinoma after receiving different doses of ionizing radiation and to provide further basis of $\alpha 2 \mathrm{M}$ application in the diagnosis and treatment of osteoradionecrosis of the jaws (ORNJ).

Methods: We use ELISA to further identify the expression of $\alpha 2 \mathrm{M}$ in the serum and urine of 30 patients with nasopharyngeal carcinoma after receiving different doses $(0 \mathrm{~Gy}, 50 \mathrm{~Gy}, 70 \mathrm{~Gy})$ of ionizing radiation and 20 healthy volunteers. Data were compared t test using 17.0 software package.

Results: The serum level of $\alpha 2 \mathrm{M}$ in patients with nasopharyngeal carcinoma has positive correlation tendency with radiation dose. Compared with the experimental groups ( $0 \mathrm{~Gy}$ and $50 \mathrm{~Gy}$ ), the serum $\alpha 2 \mathrm{M}$ level of the experimental group (70Gy) increased significantly $(\mathrm{P}<0.01)$. There was no statistically significant difference $(\mathrm{P}>0.05)$ among the urine level of $\alpha 2 \mathrm{M}$ in patients receiving different doses of radiation.

Conclusion: (1) It prompts that serum $\alpha 2 \mathrm{M}$ may be regarded as one of the early indicators monitoring the jaw damage from ionizing radiation. There should be more in-depth and systematic studies. (2) The urine level of $\alpha 2 \mathrm{M}$ in patients with nasopharyngeal carcinoma has nothing to do with radiation doses and we consider that radiation within therapeutic doses has no obvious effect on $\alpha 2 \mathrm{M}$ kidney metabolism.

Keywords: Alpha2-Macroglobulin; Nasopharyngeal Carcinoma; Ionizing Radiation; Osteoradionecrosis of the Jaws; Biomarker.

\section{Introduction}

Nasopharyngeal Carcinoma (NPC) is the most common head and neck malignant tumor [1]. Radiation therapy is the only radical treatment of NPC. It plays an important role in the first-diagnosed NPC without metastasis and is the main treatment [2]. However, RT can also cause damage to normal tissue while killing tumor cells. In the process of radiotherapy of head and neck malignant tumors, normal tissues such as oral cavity and jaw, are inevitably affected by ionizing radiation and cause various adverse reactions [3]. Osteoradionecrosis of the jaws (ORNJ) is one of the most serious complications following radiation therapy for the malignancies of the head and neck $[4,5]$. ORNJ is a progressive jaw bone necrosis, with insidious onset and tremendous clinic damage. And it may lead to a substantial deterioration in a patient's quality of life. Currently, the diagnosis of ORNJ is usually based on clinical symptoms, X-ray, CT, etc. traditional examination methods [5]. Early diagnosis of ORNJ is difficult and there are no sensitive and reliable methods to predict ORNJ. In general, the pathologic changes of bone scanned by imaging in ORNJ patients, mean that ORNJ progresses in a rapid development phase, and treatment is complex and poorly effective. Therefore, a new mini-traumatic, sensitive and special examining method of ORNJ is of great importance to early diagnosis and treatment of ORNJ. According to current bone metabolism theory, bone functions by bone unit, and the multicellular unit (BMU) of the metabolism complies of osteoblasts and osteoclasts [6]. After the completion of the bone development, bone maintains function and self-

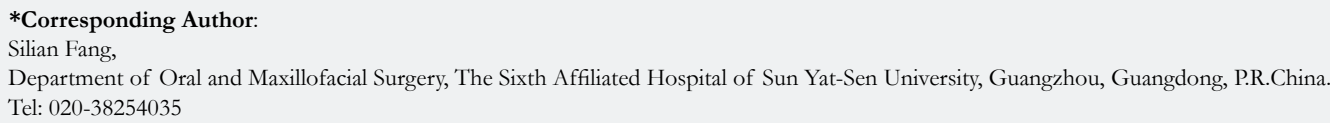

Copyright: Fang $\mathbf{S}^{\odot}$ 2018. This is an open-access article distributed under the terms of the Creative Commons Attribution License, which permits unrestricted use, distribution and reproduction in any medium, provided the original author and source are credited. 
renewal by lifelong bone reconstruction [7]. On the process of bone tissue metabolism, osteoblasts and osteoclasts will release the relative enzymes, proteins, etc. and meanwhile, the synthesis and decomposition of bone matrix also produce specific products [8]. All the products are released into the body fluids. Therefore, detecting bone metabolic products of blood and urine, can reflect the physiological and pathological state of the bone tissue. Some current bone metabolic biochemical indicators have been successfully applied to the early diagnosis and therapeutic effect monitoring of osteoporosis and other bone metabolic disease and it is noninvasive, rapid and sensitive specific and dynamic monitoring method. It can effectively make up for a defect of means of imaging examination and play an irreplaceable in the diagnosis and treatment of metabolic bone diseases.

Although ORNJ etiology is complex with many theories, the main pathological process of jaw bone damage caused by all pathogenic factors and self-regulation is the disorder of bone metabolism. So we viewed ORNJ as a specific metabolic bone disease and aimed to identify ORNJ metabolic biomarkers in human serum. In our previous study, we use 2-dimensional difference gel electrophoresis (2D-DIGE) to identify ORNJ biomarkers and characterized protein biomarkers with matrix-assisted laser desorption/ionization time-of-flight (MALDI-TOF) mass spectrometer (MS). The identified proteins were further confirmed by enzyme-linked immunosorbent assays (ELISA). $\alpha 2 \mathrm{M}$ was present at significantly decreased levels in the serum between ORNJ patients and nonORNJ patients. It is the first time that the concentration of $\alpha 2 \mathrm{M}$ was discovered significantly decreased in serum of ORNJ patients. These results suggest that $\alpha 2 \mathrm{M}$ might be the metabolic biomarker of ORNJ. Based on the results we may develop a new method which is relatively safe, easy and sensitive to early diagnose ORNJ by detecting the specific biomarkers in patient's serum.

\section{Materials and Methods}

\section{Study Patients}

All participants in the study were recruited from the fifth affiliated hospital of Sun Yat-Sen University between July 2013 and December 2013. The institutional board previously approved the study and all participants signed informed consent forms. The study was designed and conducted in accordance with the ethical principles for medical research involving human subjects from the Declaration of Helsinki. All patients were first-diagnosed as nasopharyngeal carcinoma without distant metastasis and received radiotherapy, 19 male and 11 female, 24-72 years old with a mean age of 45 years old. All tumor histologic types of NPC were poorly-differentiated squamous cell carcinoma and all patients received the standard NPC Antineoplastic Protocols meeting Union for International Cancer Control (UICC).

All patients with nasopharyngeal carcinoma received radical radiotherapy (DT 2Gy per fraction, 1 fraction per day, 5 fractions per week, with a radical dose of $70 \mathrm{~Gy}$ in 35 fractions). Healthy volunteers with no history of radiotherapy were included in the control group.

\section{Clinical Patient Information}

Thirty patients receiving radiotherapy were selected as the experi- mental group. In the experimental group, there were 19 males and 11 females, with a radio of 1.73:1. The age was between 24 and 72 years old, and the median was 45 years old. All tumor histologic types of NPC were poorly-differentiated squamous cell carcinoma, of which 19 are IIa clinical stage and 11 are IIb clinical stage. The Antineoplastic Protocols of the NPC patients were standard radiotherapy and induction chemotherapy.

Twenty healthy volunteers with no history of radiotherapy were included in the control group. In the control group, there were 9 males and 11 females, with a radio of 0.82:1. The age was between 23 and 59 years old, and the median was 27 years old.

None of the participants in our study had a history of other systemic diseases, blood transfusions or were taking any medications that could affect bone metabolism.

\section{ELISA Validation}

One hundred and ten serum and urine samples for ELISA validation were collected during the period of July 2013 to December 2013. We collected serum and urine samples of the experimental group at three different time points: before receiving radiotherapy, receiving $50 \mathrm{~Gy}$ doses of ionizing radiation and receiving $70 \mathrm{~Gy}$ doses of ionizing radiation. To detect the dynamic changes of the serum and urine alpha2-macroglobulin $(\alpha 2 \mathrm{M})$ in patients with nasopharyngeal carcinoma after receiving different doses of ionizing radiation, samples were analyzed by ELISA. Fresh wholeblood and midstream urine samples were collected from patients after a fasting state in the early morning. Coagulation of samples was allowed to occur at room temperature for $1-2 \mathrm{hr}$. The whole blood and midstream urine samples were then centrifuged for 10 min at 2,500 $\mathrm{g}$ at $4^{\circ} \mathrm{C}$. The supernatants were divided into $200-\mu \mathrm{l}$ aliquots and were stored at $-80^{\circ} \mathrm{C}$ until further analysis. ELISA assay kits for each analyte that was selected for use in further analysis were $\alpha 2 \mathrm{M}$ ELISA Kit (ICL Lab, USA). Assays were performed following the instructions provided by the kit manufacturers. Briefly, the color change due to the enzyme-substrate reaction in each well of the microtiter plate was measured spectrophotometrically at a wavelength of $450 \mathrm{~nm}$. The concentration of each tested protein in the sample was then determined by comparing the optical density (OD) to that of the standard curve.

\section{Statistical Analysis}

Statistical analysis was performed using SPSS 17.0. (SPSS Inc., USA). A descriptive and bivariate analysis was performed using the ANOVA or the Kruskal-Wallis test according to whether the data were distributed normally (Kolmogorov-Smirnov test, $\mathrm{p}$ value $<0.05)$. Multiple comparisons between each two experimental groups were further performed using paired t-test or Wilcoxon paired signed rank test according whether the data were distributed normally. A p value less than $0.05 / 3=0.017$ was considered statistically significant.

\section{Results}

\section{Validation of Identified Proteins by ELISA}

To detect the dynamic changes of the serum and urine alpha2macroglobulin $(\alpha 2 \mathrm{M})$ in patients with nasopharyngeal carcinoma 
after receiving different doses of ionizing radiation, we used ELISA to determine the levels of $\alpha 2 \mathrm{M}$, in serum and urine samples from 20 healthy volunteers and 30 NPC patients at three different time points: before receiving radiotherapy, receiving 50Gy doses of ionizing radiation and receiving $70 \mathrm{~Gy}$ doses of ionizing radiation.

There was no significant difference $(\mathrm{P}>0.05)$ between the experimental group (0Gy) and the normal control group. The serum $\alpha 2 \mathrm{M}$ level of nasopharyngeal carcinoma patients before radiotherapy was of no significant difference $(\mathrm{P}>0.05)$ in gender, age, clinical stage (Figure 1).

Comparison of the serum levels of $\alpha 2 \mathrm{M}$ among the groups of the experimental groups: the experimental group (0Gy) compared with the experiment group (70Gy), the experiment group (50Gy) compared with the experiment group (70Gy), the difference was statistically significant $(\mathrm{P}<0.017)$; the experimental group (0Gy) compared with the experiment group (50Gy), the difference was not statistically significant $(\mathrm{P}>0.017)$. So we can conclude that in patients with nasopharyngeal carcinoma radiotherapy of dose of $70 \mathrm{~Gy}$, the $\alpha 2 \mathrm{M}$ serum level increased with statistical significance compared those before radiotherapy or receiving radiotherapy dose of 50Gy. There was no obvious difference between before radiotherapy (0Gy) and receiving radiotherapy of 50Gy (Figure 2).

Comparison of the urine levels of $\alpha 2 \mathrm{M}$ among the groups of the experimental groups: there was no statistically significant difference $(\mathrm{P}>0.05)$ among the urine level of $\alpha 2 \mathrm{M}$ in patients receiving different doses of radiation (Figure 3 ).

\section{Discussion}

Human $\alpha 2 \mathrm{M}$ is a $720-\mathrm{kDa}$ glycoprotein in which five reactive sites have been characterized in each of its four identical subunits (180 $\mathrm{kDa}$ ) [9]. $\alpha 2 \mathrm{M}$ is the largest major non-immunoglobulin protein in plasma. The $\alpha 2 \mathrm{M}$ molecule is synthesized by numerous cell lineages, including lung fibroblasts, monocytes-macrophages, hepatocytes, astrocytes and adrenocortical cells [10-12].

In cultured bovine adrenocortical cells, synthesis of $\alpha 2 \mathrm{M}$ may be selectively and significantly increased by TGF- $\beta$ [12]. Interleu- kin-6 (IL-6) induces $\alpha 2 \mathrm{M}$ synthesis by human neuronal cells, a mechanism of possible significance in some diseases of the central nervous system [13]. A significant increase in $\alpha 2 \mathrm{M}$ plasma levels is consistently observed during embryogenesis, pregnancy, and childhood, all representing periods of life characterised by growth, development, and differentiation $[10,14-16] . \alpha 2 \mathrm{M}$ is a tetrameric, disulfide-rich plasma glycoprotein with several functions [9]. Some of its functions, such as inhibition of different types of nonspecific proteases and transport of cytokines, growth factors, and hormones and a pronounced immune-suppressive activity $[17,18]$, are well established.

$\alpha 2 \mathrm{M}$ is a pan-proteinase inhibitor capable of inhibiting a large variety of proteinases. After proteolytic cleavage of the "bait" region, the proteinase is entrapped and loses most of its activity, at least toward high molecular weight substrates [9]. The concomitant interruption of the thiolester triggers further biological functions of the inhibitor such as binding cytokines, growth factors and hormones $[19,20]$, as well as clearance by the $\alpha 2 \mathrm{M}-\mathrm{R} /$ LRP present on the surface of different cells [21-23]. The $\alpha 2 \mathrm{MR} /$ LRP is a $600-\mathrm{kDa}$ glycoprotein that undergoes proteolysis in the trans-Golgi and is expressed as a non-covalently associated heterodimer of 515 and $85 \mathrm{kDa}$, respectively [17]. The $\alpha 2 \mathrm{M}-\mathrm{R} / \mathrm{LRP}$ is expressed in hepatocytes where it plays an important role in the regulation of proteolytic activity in tissue and pericellular space and contributes mainly to the clearance of $\alpha 2 \mathrm{M}$-proteinase complexes from circulation [24].

Serum $\alpha 2 \mathrm{M}$ is also capable of binding to a broad spectrum of cytokines, such as transforming growth factor and basic fibroblast growth factor [25, 26] (Kruse 2004, Petersen 1993). It has been shown that $\alpha 2 \mathrm{M}$ is an irreversible inhibitor that binds bone morphogenetic protein 1 (BMP1) in a covalent complex, and it has also been demonstrated to be a potent inhibitor of similar BMPlike proteinases [27] (Zhang 2006). It has been demonstrated that tartrate-resistant acid phosphatase (TRAP) forms complexes with $\alpha 2 \mathrm{M}$ in serum, resulting in greatly decreased TRAP enzyme activity and immunoreactivity [28] (Brehme 1999). TRAP is a standard histochemical marker of differentiated osteoclasts and has been proposed as a serum/plasma marker for osteoclast activity. Enzyme assays have been described that show elevated TRAP enzyme activity in the serum or plasma of patient groups known to have increased bone metabolism [28] (Brehme 1999). Previous work has suggested a predominantly covalent mechanism of in-

Figure 1. The serum $\alpha 2 \mathrm{M}$ level of nasopharyngeal carcinoma patients before radiotherapy was of no significant difference $(P>0.05)$ in gender, age, clinical stage.

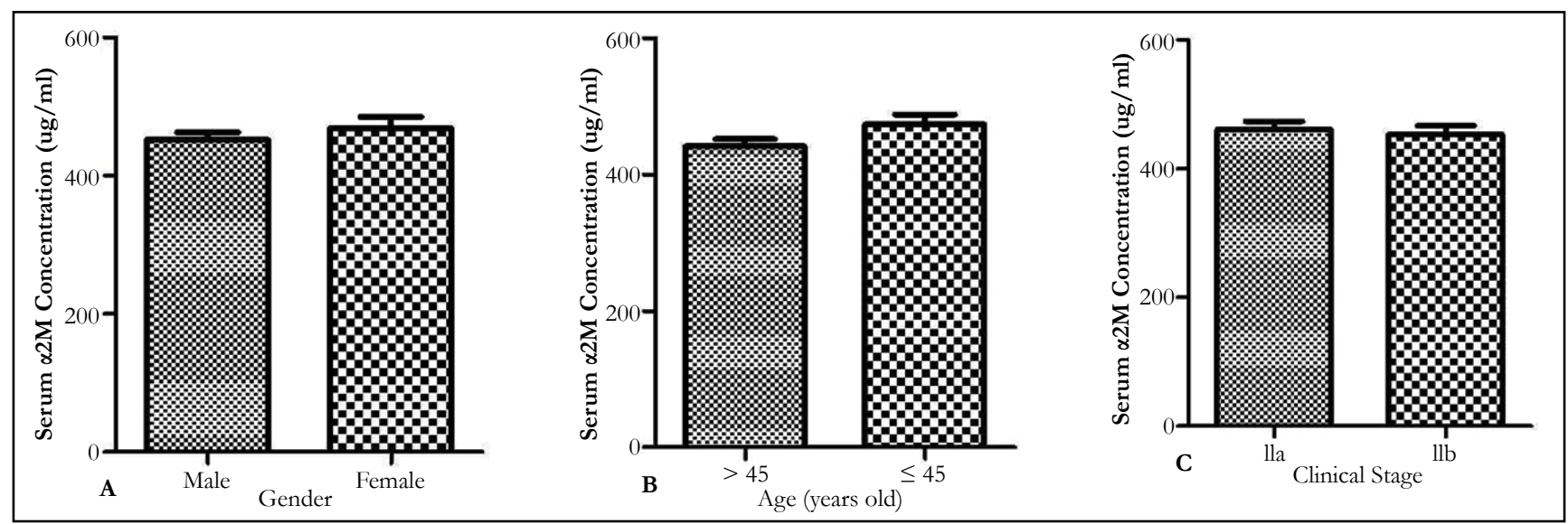


Figure 2. Comparison of the serum levels of $\alpha 2 \mathrm{M}$ among the groups of the experimental groups: the experimental group (0Gy) compared with the experiment group (70Gy), the experiment group (50Gy) compared with the experiment group (70Gy), the difference was statistically significant $(P<0.017)$; the experimental group (0Gy) compared with the experiment group (50Gy), the difference was not statistically significant $(P>0.017)$. So we can conclude that in patients with nasopharyngeal carcinoma radiotherapy of dose of $70 \mathrm{~Gy}$, the $\alpha 2 \mathrm{M}$ serum level increased with statistical significance compared those before radiotherapy or receiving radiotherapy dose of 50Gy. There was no obvious difference between before radiotherapy (0Gy) and receiving radiotherapy of $50 \mathrm{~Gy}$.

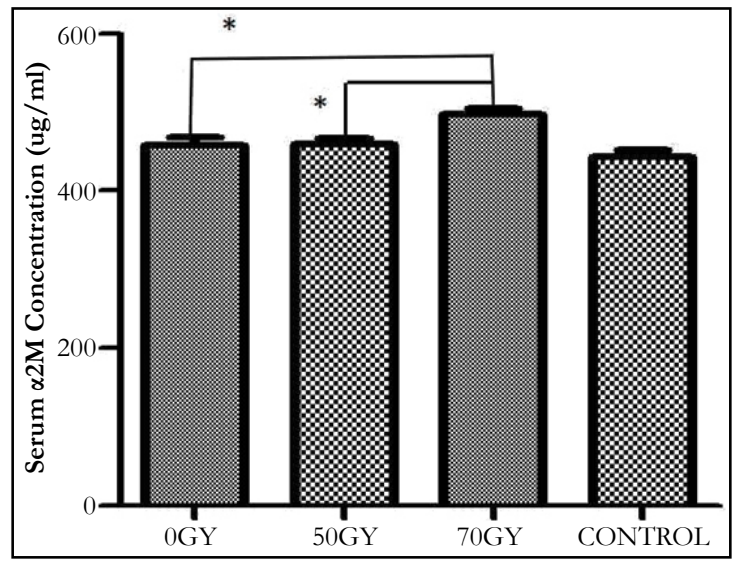

Figure 3. Comparison of the urine levels of $\alpha 2 \mathrm{M}$ among the groups of the experimental groups: there was no statistically significant difference $(P>0.05)$ among the urine level of $\alpha 2 \mathrm{M}$ in patients receiving different doses of radiation.

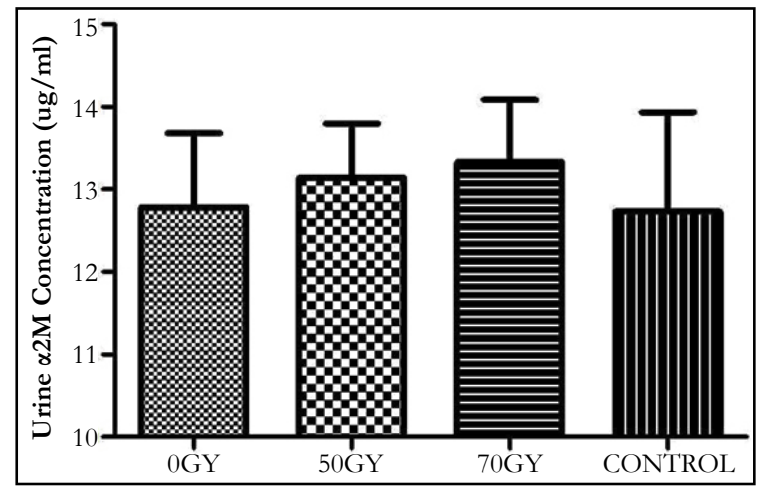

Figure 4. The potential mechanism of antioxidant effect of $\alpha 2 \mathrm{M}$ on radiation injury [50].

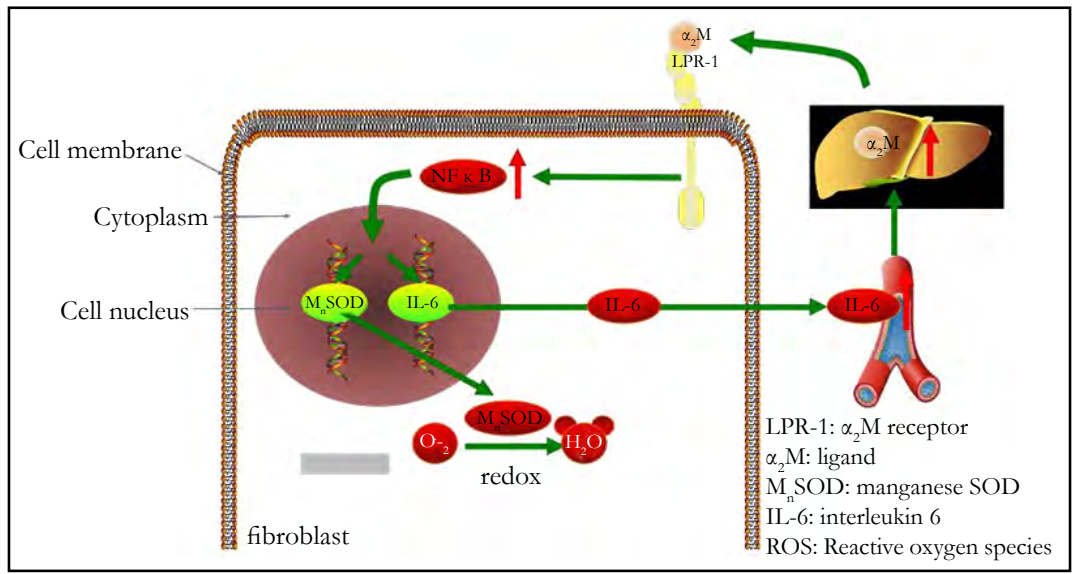

teraction between VEGF and $\alpha 2 \mathrm{M}$. VEGF is a heparin-binding, dimeric glycoprotein that plays multifunctional roles in the development of vasculature and the maintenance of vascular function. Endogenous VEGF appears to be important for bone formation and mineralization. Binding of VEGF to $\alpha 2 \mathrm{M}$ leads to the inability of VEGF to bind to its receptor [29] (Bhattacharjee 2000). The interaction of $\alpha 2 \mathrm{M}$ with its protein partners (such as BMP1, TRAP, and VEGF), which are closely related to bone metabolic processes, suggests that $\alpha 2 \mathrm{M}$ may affect bone metabolism by these proteins.

According to the theory of radiation oncology and biology, the key factor influencing the osteoradionecrosis of the jaws is the dose of ionizing radiation exposure in the extracted teeth trauma [30]. Ionizing radiation generates highly reactive oxygen radicals that react with cellular components and macromolecules, caus- 
ing damage that can, depending on the dose of exposure, result in widespread cell dysfunction, tissue destruction, and death [31] (Riley 1994). Methods to the use of conventional radiotherapy of the extracted teeth trauma, the dose below 60Gy is considered safe in clinical dose [30]. So in our study, we chose to detect the serum and urine level of $\alpha 2 \mathrm{M}$ in patients receiving the doses of $50 \mathrm{~Gy}$ and $70 \mathrm{~Gy}$ ionizing radiation respectively. The two doses of ionizing radiation were below and above the safe dose $60 \mathrm{~Gy}$. So by comparing the serum and urine level of $\alpha 2 \mathrm{M}$ of in patients receiving the two doses of ionizing radiation, it could prompt that the serum and urine level of $\alpha 2 \mathrm{M}$ when the jaw got early radiation injury after receiving intensity modulated radiotherapy on tumors of head and neck. We studied that whether the serum and urine level changes of $\alpha 2 \mathrm{M}$ was meaningful or not during the early stage of radiation injury.

In this study, the experimental group (0Gy) compared with the experiment group (70Gy), the experiment group (50Gy) compared with the experiment group (70Gy), the difference was statistically significant $(\mathrm{P}<0.017)$; the experimental group (0Gy) compared with the experiment group (50Gy), the difference was not statistically significant $(\mathrm{P}>0.017)$. So we can conclude that in patients with nasopharyngeal carcinoma radiotherapy of dose of $70 \mathrm{~Gy}$, the $\alpha 2 \mathrm{M}$ serum level increased with statistical significance compared those before radiotherapy or receiving radiotherapy dose of 50Gy. There was no obvious difference between before radiotherapy (0Gy) and receiving radiotherapy of 50Gy. As the safe dose of ionizing radiation is $60 \mathrm{~Gy}$, when the dose is below the safe dose, the jaw doesn't get radiation injury and the serum level of $\alpha 2 \mathrm{M}$ is normal. When patients got radiotherapy dose of $70 \mathrm{~Gy}$ ionizing radiation, above the safe dose, the jaw got radiation injury and the serum level of $\alpha 2 \mathrm{M}$ increased. Increased expression or lowed metabolism could result in the increased serum level of $\alpha 2 \mathrm{M}$. We inferred that $\alpha 2 \mathrm{M}$ played an important role in radioprotection mechanism of jaws. The serum levels of alpha2macroglobulin in nasopharyngeal carcinoma patients receiving late period radiotherapy increased $(\mathrm{P}<0.017)$ and it prompted that $\alpha 2 \mathrm{M}$ may be an early specific biomarker for radiation injury of jaws.

Recent studies have shown that $\alpha 2 \mathrm{M}$ possesses radioprotective effects, but the radioprotection mechanism of $\alpha 2 \mathrm{M}$ against jaws radiation injury has not been reported yet. Evidence implicates the $\alpha 2$-macroglobulin fraction (19S) (containing $\alpha 2 \mathrm{M}$ ) in the recovery of mice from radiation damage. The $\alpha 2$-macroglobulin fraction has been shown to enhance the regeneration of haematopoietic cells [32] and lymphopoietic cells [33] in X-irradiated mice. The haematopoietic system is among the most radiosensitive tissues in the body.

$\alpha 2 \mathrm{M}$ most likely plays a role in maintaining hemodynamic equilibrium because the primary cause of death after repeated scalding is circulatory shock provoked by a decrease in plasma volume of more than $50 \%$ [34]. This is supported by the finding that $\alpha 2 \mathrm{M}$ inhibits the activity of prostaglandin E2, which increases the permeability of blood vessels [35] and acts as a vasodilator [36].

$\mathrm{S}^{\vee}$ evaljevic' et al., reported that the administration of the rat acute-phase (AP) protein a2-macroglobulin $(\alpha 2 \mathrm{M})$ that results in a 15 -fold increase in its concentration from the normal basal level, 30 min either before the infliction of a lethal scalding [37] or ex- posure to total body irradiation with 6.7 Gy (LD50/30) X-rays $[38,39]$ enabled $100 \%$ survival in experimental animals. Indeed, pretreatment with $\alpha 2 \mathrm{M}$ before whole-body irradiation allowed for the restoration of body weight, leukocyte count, the complete recovery of liver mass and fully protected liver morphology during a 4 week follow-up period covering the duration of the ARS. Otherwise, pretreatment with $\alpha 2 \mathrm{M}$ also induced a significant reduction of irradiation-induced DNA damage and the complete restoration of liver and body weight. Mihailović Mirjana et al., conclude that the radioprotection provided by $\alpha 2 \mathrm{M}$ was in part mediated through cytoprotection of new blood cells produced in the bone marrow and they also indicate that an important aspect of the radioprotective effect of amifostine is the result of induction of the endogenous cytoprotective capability of $\alpha 2 \mathrm{M}$ $[39,40]$. Mihailovic et al., (2009) compare the cytoprotective effects of $\alpha 2 \mathrm{M}$ and amifostine on rat liver. At 2 weeks after irradiation, Comet assays revealed a 15 -fold increase in DNA damage in unprotected rats, while in $\alpha 2 \mathrm{M}$ - and amifostine-treated rats we observed 3- and 4- fold rise in damage, respectively [41].

Ionizing radiation causes immediate direct damage to macromolecules and also generates reactive oxygen species (ROS) in irradiated tissues and cells [42]. The antioxidant system in the liver includes enzymatic and non-enzymatic components that control the flux of ROS [42]. The first line of defence against increased levels of ROS is provided by the activities of the major antioxidant enzymes such as superoxide dismutase (SODs) that inactivates the superoxide anion by catalysing its dismutation into oxygen and hydrogen peroxide, and catalase that inactivates the peroxide [43]. The enhancement of endogenous intracellular antioxidant enzyme levels can be very important in the adaptive, inherent radiation resistance of cells. An example is manganese superoxide dismutase (MnSOD), which was identified as the most effective endogenous antioxidant enzyme in protecting against radiation-induced cell toxicity [44]. Mihailovic et al., (2011) reported that pretreatment with $\alpha 2 \mathrm{M}$ led to increased levels of the inflammatory cytokine IL- 6 and the redox-sensitive transcription factor $\mathrm{NF} x \mathrm{~B}$ (p65), promoting upregulation of $\mathrm{MnSOD}$, the major component of the cell's antioxidant axis, and subsequent increases in $\mathrm{Mn} / \mathrm{CuZnSOD}$ and catalase enzymatic activities [41]. As $\alpha 2$-Macroglobulin is a carrier protein for IL- 6 , the powerful inducer of its synthesis, these two proteins can modulate each other's activity. It does not inhibit IL-6 activity or its binding to homologous receptor. In addition, IL- 6 bound to $\alpha 2 \mathrm{M}$ is resistant to proteinases, whereas free IL- 6 is easily degraded [45]. NFxB is predominantly comprised of $\mathrm{p} 65 / \mathrm{p} 50$ heterodimers that are sequestered in the cytoplasm by association with members of the I $\kappa \mathrm{B}$ protein family, which bind $\mathrm{NF \kappa B}$ and thereby mask its nuclear localisation signal. Upon stimulation by inflammatory cytokines or DNA damage, I $\kappa \mathrm{B}$ molecules are degraded, promoting the nuclear translocation of $\mathrm{NF \kappa B}$ and binding to target genes. Only p65 and c-Rel activate transcription [46]. Pretreatment with $\alpha 2 \mathrm{M}$ led to increased levels of NFKB (p65), increased nuclear transcription signals, and activation target genes (e.g., MnSOD gene) resulting in increased protein expression. Superoxide dismutase (SOD) enzymes are naturally occurring intracellular enzymes, which scavenge O2-by catalysing its conversion to hydrogen peroxide and oxygen. It has become clear that these enzymes provide an essential defence against the superoxide radical. The copper-, zinc-and manganese-containing SODs ( $\mathrm{Cu}, \mathrm{Zn}, \mathrm{Mn}$ and SOD) are the most common type of SOD $[47,48] . \mathrm{Mn} / \mathrm{CuZnSOD}$ and catalase are naturally occurring antioxidant enzymes and $\alpha 2 \mathrm{M}$ lead 
to subsequent increases in $\mathrm{Mn} / \mathrm{CuZnSOD}$ and catalase enzymatic activities and then the ability of free radical scavenging increases.

Combined with radiation-induced fibrosis theory, the antioxidant effect of $\alpha 2 \mathrm{M}$ on radiation injury may be as follows [49] (Figure 4). $\alpha 2 \mathrm{M}$ binds LRP-1 on the fibroblast membrane and sends the signal to $\mathrm{NF} \varkappa \mathrm{B}$ and promotes the nuclear translocation of $\mathrm{NF} \varkappa \mathrm{B}$ and binds to target genes (MnSOD and IL- 6 genes), and then the expression of MnSOD and IL-6 increases. MnSOD scavenges O2- by catalysing its conversion to hydrogen peroxide and oxygen. IL- 6 enters the blood circulation and reaches the liver to induce the synthesis of $\alpha 2 \mathrm{M}$. Then, $\alpha 2 \mathrm{M}$ binds LRP-1 on the fibroblast membrane again. In our study, we detected that the serum level of $\alpha 2 \mathrm{M}$ in patients receiving 70Gy (above safe dose: $60 \mathrm{~Gy})$ ionizing radiation increased $(\mathrm{P}<0.01)$. It implicates that $\alpha 2 \mathrm{M}$ plays a role in radioprotection, but the mechanism is still not clear and more researches in vivo and in vitro are needed.

In this study, we also detected the urine level of $\alpha 2 \mathrm{M}$ in NPC patients receiving different doses of radiotherapy. There was no statistically significant difference $(\mathrm{P}>0.05)$ among the urine level of $\alpha 2 \mathrm{M}$ in patients receiving different doses of radiation. It implies that the kidney metabolism of $\alpha 2 \mathrm{M}$ doesn't change obviously during the early period of ionizing radiation injury. The increase of serum level of $\alpha 2 \mathrm{M}$ during the early stage of radiation injury results from increased expression.

\section{Conclusion}

It prompts that serum $\alpha 2 \mathrm{M}$ may be regarded as one of the early indicators monitoring the jaw damage from ionizing radiation. There should be more in-depth and systematic studies. The urine level of $\alpha 2 \mathrm{M}$ in patients with nasopharyngeal carcinoma has nothing to do with radiation doses and we consider that radiation within therapeutic doses has no obvious effect on $\alpha 2 \mathrm{M}$ kidney metabolism.

\section{Acknowledgement}

This research was supported by The Sixth Affiliated Hospital of Sun Yat-Sen University, Guangzhou, Guangdong, 510655, P.R. China. I thank Professor Fang for guidance in related fields and assistance with the English language revision.

\section{Funding}

This publication was supported by grant of the Science and Technology Planning Project of Guangdong Province (2017A010105027), the Project supported by the Natural Science Foundation of Guangdong Province China (2015A030313064), the Special Fund Project for Public Welfare Research and Capacity Building of Guangdong Province(2014A020212167) and Medical Science and Technology Research Fund Project of Guangdong Province (A2015059).

\section{References}

[1]. Ma J, Cao S. The epidemiology of nasopharyngeal carcinoma. In Nasopharyngeal Cancer. Springer, Berlin, Heidelberg; 2010. p. 1-7.

[2]. Madrid C, Abarca M, Bouferrache K. Osteoradionecrosis: an update. Oral Oncol. 2010 Jun;46(6):471-4. PubMed PMID: 20457536.

[3]. Sciubba JJ, Goldenberg D. Oral complications of radiotherapy. Lancet On- col. 2006 Feb;7(2):175-83. PubMed PMID: 16455482.

[4]. Lyons A, Ghazali N. Osteoradionecrosis of the jaws: current understanding of its pathophysiology and treatment. Br J Oral Maxillofac Surg. 2008 Dec;46(8):653-60. PubMed PMID: 18562055.

[5]. Kaunitz JD, Yamaguchi DT. TNAP, TrAP, ecto-purinergic signaling, and bone remodeling. J Cell Biochem. 2008 Oct 15;105(3):655-62. doi: 10.1002/jcb.21885. PubMed PMID: 18773425.

[6]. De Leo V, Ditto A, La Marca A, Lanzetta D, Massafra C, Morgante G. Bone mineral density and biochemical markers of bone turnover in peri-and postmenopausal women. Calcif Tissue Int. 2000 Apr;66(4):263-7. PubMed PMID: 10742442

[7]. Civitelli R, Armamento-Villareal R, Napoli N. Bone turnover markers: understanding their value in clinical trials and clinical practice. Osteoporos Int. 2009 Jun;20(6):843-51. doi: 10.1007/s00198-009-0838-9. Epub 2009 Feb 4. PubMed PMID: 19190842.

[8]. Al-Nawas B, Duschner H, Grötz KA. Early cellular alterations in bone after radiation therapy and its relation to osteoradionecrosis. J Oral Maxillofac surg. 2004 Aug 1;62(8):1045.

[9]. Sottrup-Jensen L. Alpha-macroglobulins: structure, shape, and mechanism of proteinase complex formation. J Biol Chem. 1989 Jul 15;264(20):1153942. PubMed PMID: 2473064.

[10]. Sottrup-Jensen L. 2-Macroglobulin and related thiol ester plasma proteins. The Plasma Proteins. 1987;5:191-291.

[11]. Matthijs G, Devriendt K, Cassiman JJ, Van den Berghe H, Marynen P. Structure of the human alphas-macroglobulin gene and its promoter. Biochem. Biochem Biophys Res Commun. 1992 Apr 30;184(2):596-603. PubMed PMID: 1374237.

[12]. Shi DL, Savona C, Gagnon J, Cochet C, Chambaz EM, Feige JJ. Transforming growth factor-beta stimulates the expression of alpha 2-macroglobulin by cultured bovine adrenocortical cells. J Biol Chem. 1990 Feb 15;265(5):28817. PubMed PMID: 1689294.

[13]. Strauss S, Bauer J, Ganter U, Jonas U, Berger M, Volk B. Detection of interleukin-6 and alpha 2-macroglobulin immunoreactivity in cortex and hippocampus of Alzheimer's disease patients. Lab Invest. 1992 Feb;66(2):22330. PubMed PMID: 1370967.

[14]. Harpel PC. Human alpha2-macroglobulin. In: Lorand L. eds. Methods Enzymol. 1976;45:639-52. PubMed PMID: 64914.

[15]. Goldenberg RL, Tamura T, Cliver SP, Cutter GR, Hoffman HJ, Davis RO. Maternal serum alpha 2-macroglobulin and fetal growth retardation. Obstet Gynecol. 1991 Oct;78(4):594-9. PubMed PMID: 1717906.

[16]. Ganrot PO, Schersten B. Serum $\alpha 2$-macroglobulin concentration and its variation with age and sex. Clinica Chimica Acta. 1967 Jan 1;15(1):113-20.

[17]. Borth W. Alpha 2-macroglobulin, a multifunctional binding protein with targeting characteristics. FASEB J. 1992 Dec;6(15):3345-53. PubMed PMID: 1281457.

[18]. Acosta JA, Hoyt DB, Schmid-Schönbein GW, Hugli TE, Anjaria DJ, Frankel DA, Coimbra R. Intraluminal pancreatic serine protease activity, mucosal permeability, and shock: a review. Shock. 2006 Jul;26(1):3-9. PubMed PMID: 16783190.

[19]. LaMarre J, Wollenberg GK, Gonias SL, Hayes MA. Cytokine binding and clearance properties of proteinase-activated alpha 2-macroglobulins. Lab Invest. 1991 Jul;65(1):3-14. PubMed PMID: 1712874.

[20]. Kratzsch JO, Selisko TH, Birkenmeier GE. Identification of transformed alpha 2-macroglobulin as a growth hormone-binding protein in human blood. J Clin Endocrinol Metab. 1995 Feb;80(2):585-90. PubMed PMID: 7531714 .

[21]. Moestrup SK, Gliemann J, Pallesen G. Distribution of the $\alpha$ 2-macroglobulin receptor/low density lipoprotein receptor-related protein in human tissues. Cell Tissue Res. 1992 Sep;269(3):375-82. PubMed PMID: 1423505.

[22]. Herz J, Hamann U, Rogne S, Myklebost O, Gausepohl H, Stanley KK. Surface location and high affinity for calcium of a 500-kd liver membrane protein closely related to the LDL-receptor suggest a physiological role as lipoprotein receptor. EMBO J. 1988 Dec 20;7(13):4119-27. PubMed PMID: 3266596.

[23]. Strickland DK, Ashcom JD, Williams S, Burgess WH, Migliorini M, Argraves WS. Sequence identity between the alpha 2-macroglobulin receptor and low density lipoprotein receptor-related protein suggests that this molecule is a multifunctional receptor. J Biol Chem. 1990 Oct 15;265(29):174014. PubMed PMID: 1698775.

[24]. Strickland DK, Kounnas MZ, Argraves WS. LDL receptor-related protein: a multiligand receptor for lipoprotein and proteinase catabolism. FASEB J. 1995 Jul;9(10):890-8. PubMed PMID: 7615159.

[25]. Kruse MN, Becker C, Lottaz D, et al. Human meprin alpha and beta homooligomers: cleavage of basement membrane proteins and sensitivity to metalloprotease inhibitors. Biochem J. 2004 Mar 1;378(Pt 2):383-9. PubMed PMID: 14594449.

[26]. Petersen CM. Alpha 2-macroglobulin and pregnancy zone protein. Serum 
levels, alpha 2-macroglobulin receptors, cellular synthesis and aspects of function in relation to immunology. Dan Med Bull. 1993 Sep;40(4):40946. PubMed PMID: 7693397.

[27]. Zhang Y, Ge G, Greenspan DS. Inhibition of bone morphogenetic protein 1 by native and altered forms of $\alpha 2$-macroglobulin. J Biol Chem. $2006 \mathrm{Dec}$ 22;281(51):39096-104. Epub 2006 Oct 27. PubMed PMID: 17071617.

[28]. Brehme CS, Roman S, Shaffer J, Wolfert R. Tartrate-Resistant Acid Phosphatase Forms Complexes with $\alpha_{2}$-Macroglobulin in Serum. J Bone Miner Res. 1999 Feb;14(2):311-8. PubMed PMID: 9933487.

[29]. Bhattacharjee G, Asplin IR, Wu SM, Gawdi G, Pizzo SV. The conformationdependent interaction of alpha 2-macroglobulin with vascular endothelial growth factor. A novel mechanism of alpha 2-macroglobulin/growth factor binding. J Biol Chem. 2000 Sep 1;275(35):26806-11. PubMed PMID: 10862607.

[30]. Tong AC, Leung AC, Cheng JC, Sham J. Incidence of complicated healing and osteoradionecrosis following tooth extraction in patients receiving readiotherapy for treatment of nasopharyngeal carcinoma. Aust Dent J. 1999 Sep;44(3):187-94. PubMed PMID: 10592563.

[31]. Free radicals in biology: oxidative stress and the effects of ionizing radiation. Int J Radiat Biol. 1994 Jan;65(1):27-33. PubMed PMID: 7905906.

[32]. Hanna MG, Nettesheim P, Fisher WD, Peters LC, Francis MW. Serum alpha globulin fraction: survival-and-recovery effect in irradiated mice. Science. 1967 Sep 22;157(3795):1458-61. PubMed PMID: 4166809.

[33]. Berenblum I, Burger M, Knyszynski A. Regeneration of bone marrow cells and thymus induced by 195 alpha- 2 globulin in irradiated mice. Nature. 1968 Mar 2;217(5131):857-8. PubMed PMID: 5641150.

[34]. Cotran RS, Remensnyder JP. The structural basis of increased vascular permeability after graded thermal injury-light and electron microscopic studies. Ann NY Acad Sci. 1968 Aug 1;150(1):495-509.

[35]. Van Vugt H, Van Gool J, De Ridder L. Alpha 2 macroglobulin of the rat, an acute phase protein, mitigates the early course of endotoxin shock. Br J Exp Pathol. 1986 Jun;67(3):313-9. PubMed PMID: 2424486.

[36]. Ufkes JG, Ottenhof M, Labruyere WT, et al. The effects of alpha M-foetoprotein, an acute phase protein, and BaSO4-induced injury on IgE-mediated, systemic anaphylaxis in the rat. Br J Exp Pathol. 1986 Jun;67(3):321-7. PubMed PMID: 2424487.

[37]. Ševaljević L, Petrović M, Bogojević D. Pretreatment with $\alpha 2$-macroglobulin leads to recovery of rats exposed to a lethal scald. Burns. 1994 Apr;20(2):1227. PubMed PMID: 7515246.

[38]. Ševaljević L, Dobrić S, et al. The Radioprotective Activities of Turpentine-induced Inflammation and $\alpha 2$-Macroglobulin: The Effect of Dexamethasone on the Radioprotective Efficacy of the Inflammation. J Radiat Res. 2003 Mar 1;44(1):59-67.
[39]. Mirjana M, Silva D, Goran P, et al. The acute-phase protein $\alpha 2$ macroglobulin plays an important role in radioprotection in the rat. Shock. 2009 Jun 1;31(6):607-14.

[40]. Mihailovic M, Milosevic V, Grigorov I, Poznanovic G, Ivanovic-Matic S, Grdovic N, Bogojevic D. The radioprotective effect of alpha2-macroglobulin: A morphological study of rat liver. Med Sci Monit. 2009 Jul;15(7):BR188-93. PubMed PMID: 19564818.

[41]. Bogojević D, Poznanović G, Grdović N, Grigorov I, Vidaković M, Dinić S, Mihailović M. Administration of rat acute-phase protein $\alpha_{2}$-macroglobulin before total-body irradiation initiates cytoprotective mechanisms in the liver. Radiat Environ Biophys. 2011 Mar;50(1):167-79. PubMed PMID: 20848291.

[42]. Riley PA. Free radicals in biology: oxidative stress and the effects of ionizing radiation. Int J Radiat Biol. 1994 Jan;65(1):27-33. PubMed PMID: 7905906.

[43]. Fridovich I. Superoxide radical and superoxide dismutases. Annu Rev Biochem. 1995;64:97-112. PubMed PMID: 7574505.

[44]. Murley JS, Kataoka Y, et al. Delayed radioprotection by nuclear transcription factor $\kappa \mathrm{B}$-mediated induction of manganese superoxide dismutase in human microvascular endothelial cells after exposure to the free radical scavenger WR1065. Free Radic Biol Med. 2006 Mar 15;40(6):1004-16. PubMed PMID: 16540396

[45]. Matsuda T, Hirano T, Nagasawa S, Kishimoto T. Identification of alpha 2-macroglobulin as a carrier protein for IL-6. J Immunol. 1989 Jan 1;142(1):148-52. PubMed PMID: 2462586.

[46]. Daosukho C, Kiningham K, Kasarskis EJ, Ittarat W, Clair DK. Tamoxifen enhancement of TNF- $\alpha$ induced MnSOD expression: modulation of NF- $\kappa \mathrm{B}$ dimerization. Oncogene. 2002 May 16;21(22):3603-10. PubMed PMID: 12032862.

[47]. Epperly MW, Defilippi S, Sikora C, et al. Intratracheal injection of manganese superoxide dismutase (MnSOD) plasmid/liposomes protects normal lung but not orthotopic tumors from irradiation. Gene Ther. 2000 Jun;7(12):1011-8. PubMed PMID: 10871749.

[48]. Vujaskovic Z, Batinic-Haberle I, et al. A small molecular weight catalytic metalloporphyrin antioxidant with superoxide dismutase (SOD) mimetic properties protects lungs from radiation-induced injury. Free Radic Biol Med. 2002 Sep 15;33(6):857-63. PubMed PMID: 12208373.

[49]. Chen X, Kong X, Zhang Z, Chen W, Chen J, Li H, Cao W, Ge Y, Fang S. Alpha-2-macroglobulin as a radioprotective agent: a review. Chin J Cancer Res. 2014 Oct;26(5):611-21. PubMed PMID: 25400428.

[50]. Chen X, Kong X, Zhang Z, et al. Alpha-2-macroglobulin as a radioprotective agent: a review. Chin J Cancer Res. 2014 Oct;26(5):611-21. PubMed PMID: 25400428. 